\title{
Cause-Related Marketing in the Telecom Sector: Understanding the Dynamics among Environmental Values, Cause-Brand Fit, and Product Type
}

\author{
Tsungjen Shih ${ }^{1}\left(\mathbb{D}\right.$ and Shaojung Sharon Wang ${ }^{2, *}$ \\ 1 International Master's Program in International Communication Studies, National Chengchi University, \\ Taipei City 11605, Taiwan; tjshih@gmail.com \\ 2 Institute of Marketing Communication, National Sun Yat-sen University, Kaohsiung 80424, Taiwan \\ * Correspondence: shaowang@faculty.nsysu.edu.tw
}

Citation: Shih, T.; Wang, S.S. Cause-Related Marketing in the Telecom Sector: Understanding the Dynamics among Environmental Values, Cause-Brand Fit, and Product Type. Sustainability 2021, 13, 5129. https://doi.org/10.3390/su13095129

Academic Editors: Umberto Panniello and Roma Paolo

Received: 27 March 2021

Accepted: 29 April 2021

Published: 3 May 2021

Publisher's Note: MDPI stays neutral with regard to jurisdictional claims in published maps and institutional affiliations.

Copyright: (C) 2021 by the authors. Licensee MDPI, Basel, Switzerland. This article is an open access article distributed under the terms and conditions of the Creative Commons Attribution (CC BY) license (https:// creativecommons.org/licenses/by/ $4.0 /)$.

\begin{abstract}
Due to heightened ecological awareness and concern in recent years, many businesses have started to employ cause-related marketing (CRM) strategies aiming at communicating sustainabilitybased value to their potential targets. Building on the growing body of research on cause-brand fit and product types, the present study incorporates environmental values to explore the effectiveness of CRM messages in the telecom industry. A $4 \times 2$ online experiment was conducted in which a total of 1175 adults in Taiwan participated. The results demonstrated that CRM campaigns were effective for increasing perceived corporate image and purchase intentions. However, corporate image and purchase intentions did not vary with different levels of cause-brand fit. The results also showed that corporate image mediated the relationship between CRM campaigns and purchase intentions. Furthermore, this indirect relationship was moderated by environmental values, especially for necessary products. Theoretical and practical implications on corporate social responsibility to promote environmental sustainability are discussed.
\end{abstract}

Keywords: cause-brand fit; cause-related marketing; environmental values; product type; sustainability; telecommunications industry

\section{Introduction}

The United Nations (UN) Sustainable Development Goals (SDGs) have laid out a clear roadmap regarding how human society may be improved in the future. Ratified by many nations, the SDGs differ from previous UN sustainable development plans by shifting the onus of responsibility from governments to all social sectors, including business [1]. In particular, SDG 17 explicitly calls upon business enterprises to strengthen partnerships and assist governments in implementing other SDGs [2]. For the telecom industry, it is particularly urgent to act in an environmental-friendly and sustainable manner because of the adverse ecological impacts the industry has exerted. Among others, the industry builds mobile telephone towers that have health implications, produces short life-cycle equipment that increases electronic waste, and consumes large amounts of energy at the infrastructure level to meet individuals' demands for fast, reliable, and affordable services. Environmental responsibility is, therefore, on top of the agenda for the telecom industry.

Global telecom companies, such as AT\&T, the BT Group, and Telefonica, have joined the Climate Group and pledged to use 100\% renewable energy. Taiwan Mobile (TWM), one of the largest telecommunications companies in Taiwan, has a corporate social responsibility (CSR) section on its front page and has used the 17 UN SDGs as a guiding principle. While telecom companies increasingly embrace environmental CSR to fulfill their social duties, scant research has empirically evaluated the effects of such practice.

In general, existing literature about the effect of environmentally directed initiatives were mixed. Some researchers found that promoting environmental causes cannot predict 
individuals' purchasing intentions [3,4] while others suggested that individuals showed a higher level of purchase intention if a company was perceived to have better environmental performance [5]. These studies suggested that environmental causes may be more attractive for some consumer segments than for others [6]. In particular, in compliance with the expectations, many telecom companies have started to employ cause-related marketing (CRM) as a way to demonstrate their commitment to sustainability while, at the same time, making profits. However, the effects of CRM were not always positive and that the fit between the cause and the brand may affect the consequences of a CRM initiative [7], requiring further investigation.

To date, a plethora of research has demonstrated the relationship between causebrand fit and individuals' attitudes toward the brands as well as their purchase intentions (e.g., $[8,9])$. Other researchers have indicated that cause-brand fit could interact with individual factors to shape people's attitudinal or behavioral outcomes [10]. One important pre-dispositional factor that may affect how people make sense of CRM messages is environmental values. Such values are conceptualized as having three integral parts: egoistic values, altruistic values, and biospheric values [11]. So far, very few studies have integrated environmental values into the examination of CRM effects. Previous research has indicated that environmental values are positively associated with environmental citizenship, which includes practices such as green buying [12]. However, how those values may interact with CRM activities and shape people's reactions is less clear. It is, therefore, imperative to examine whether environmental values would serve as a perceptual filter that guides the way people process CRM messages.

The effects of CRM may also vary with the product type. Research has suggested that CRM activities are more effective for promoting frivolous products than for promoting practical products [13]. However, existing research focused mainly on the affective motivations leading to the purchase of hedonic products (e.g., [14]). Less is known about how other incentives may function in people's decision-making process. To the extent that altruistic concerns played a more prominent role for hedonic products than practical products [13], it is of great importance to examine how environmental values may strengthen or attenuate CRM effects.

Taken together, the present study integrates environmental values into the growing body of research on cause-brand fit and product types to explore the effectiveness of CRM messages in the telecom industry. The goal is trifold. First, this study examines the effect of different levels of cause-brand fit on perceptions of corporate image and purchase intentions, and investigates the mechanisms through which CRM activities exert an impact, paying specific attention to corporate image. Second, the study incorporates the concept of environmental values as a form of cause involvement into CRM research by examining how these values shape people's interpretations of CRM information. Last, this study looks into the dynamics of CRM and other moderating factors in the context of different product types, in order to broaden the understanding of the phenomenon. To the extent that this study aims to examine the effect of CRM, we will employ between-subject experimental design as the research method.

\section{Theoretical Framework, Hypotheses, and Research Questions}

\subsection{Cause-Related Marketing}

As mentioned earlier, more and more companies are integrating environmental causes into their marketing campaigns. However, empirical studies focusing on the effect of environmental CRM are lacking, creating a gap between practice and research. In one of the few studies, Lerro et al. [15] found that environmental CRM campaigns changed people's preferences for chocolate brands, although other causes (i.e., social, local community, and non-local community) were equally effective. Due to the scarcity of relevant research, we discussed the effects of CRM in general rather than focus specifically on the environmental dimension of CRM. 
CRM is defined as "the process of formulating and implementing marketing activities that are characterized by an offer from the firm to contribute a specified amount to a designated cause when customers engage in revenue-providing exchanges that satisfy organizational and individual objectives" [16]. Whereas CSR outlines a company's general commitment to satisfying social needs, CRM refers to marketing communication activities through which the company integrates its social responsibility to its marketing programs [17]. In this study, we focus on research findings specifically about CRM, but refer to CSR only when addressing the larger research context where CRM is embedded.

Three types of CRM have been identified: transaction-based (in which a certain percentage of profit or sales are donated to a cause), joint issue promotion (in which a brand/corporation and nonprofit organization (NPO) join together to promote a cause through marketing strategies), and licensing the names and logos of NPOs to a brand/corporation for a fee or percentage of revenues [18]. Among them, the first type may be most commonly used [18]. A classic example is American Express's CRM campaign, in which the company donated a cent for each use of its charge card to support the restoration of the Statue of Liberty.

Past research has suggested a positive relationship between CRM activities and corporate image $[10,19,20]$, or "the features of the company that stakeholders come to perceive" [21]. This positive association was confirmed in different types of companies, such as a high-tech company [22], a company in the hospitality industry [23], and a company in the insurance sector [24].

Many studies to date have examined the impact of CRM campaigns on purchase intentions, defined as the probability that individuals intend to purchase a particular product or service [25]. Intentions are considered an indicator of the extent to which individuals are willing to practice particular behaviors and their attempts to perform those behaviors [26]. Given the nature of experimental design, the present study explored how a corporation's CRM may affect purchase intentions rather than their actual purchase behavior.

In general, research has shown a positive relationship between CRM activities and purchase intentions $[27,28]$, but there are conditions in which CRM campaigns may fail to function properly or may even produce counter effects. For example, people's beliefs about a company's motives to engage in CRM may shape how they interpret the activity. If people perceive the CRM activity as self-interested or profit-oriented, they might become skeptical about the purpose of the CRM, which, in turn, may hurt the company's reputation [29]. Indeed, researchers have found that, when people considered a CRM to be proactive or altruistic, their attitudes toward the company became more favorable and their purchase intentions increased, whereas when they perceived a CRM to be reactive or self-serving, their evaluation of the company and their purchase intentions were lower [30]. Such studies demonstrate the need to look more granularly at the impacts of CRM campaigns by examining the conditions under which CRM may exert different effects.

\subsection{The Effect of Cause-Brand Fit on Corporate Image and Purchase Intentions}

Cause-brand fit refers to the degree of congruency, similarity, or compatibility that people perceive between a particular cause and a brand [7]. Research has shown that cause-brand fit is positively associated with a variety of attitudinal or behavioral outcomes, including brand image [31], attitude toward brand and products [9,10], attitude toward the CRM [8], and purchase intentions [32,33].

The importance of cause-brand fit can be explained by the schema congruity framework. A schema is a hypothetical structure in one's memory that guides perceptions, thoughts, and actions in order to process new stimuli without allocating many cognitive resources [34]. The schema congruity framework explains how individuals evaluate new encounters relative to existing situations based on expectations about the activated schema, which may be either congruent or incongruent with the incoming information.

Congruent information requires low arousal and less cognitive effort to process than incongruent information [35]. Thus, congruent information may create mildly positive effects because people are more comfortable with the similarity between the new stimuli 
and existing schemas. In contrast, incongruity requires considerably more effort and cognitive resources for processing. However, this heightened arousal that occurs with incongruity may lead to higher awareness [36] and attention [37], indirectly leading to positive attitudes or behavioral outcomes [38].

In the field of CRM, researchers have focused on how corporates deliver their social and environmental commitment to influence individuals' attitudes and responses as products or services are sold to a large extent by the corporate's image. However, the results vary due to the levels of cause-brand fit. Studies have shown that the effect of CRM on corporate image and purchase intention was stronger when cause-brand fit was high $[8,32,33,39]$. Furthermore, when cause-brand fit was high, individuals' perceived brand attitude was formed based on the CRM activity, but when cause-brand fit was low, individuals evaluated brand image mainly based on perceived corporate ability in producing products or services [32].

However, other studies have suggested that, when cause-brand fit is low, marketing campaigns are more positively evaluated [40], and still others have found that the fit between a cause and brand did not affect individuals' attitudes toward the brand and company nor their purchase intentions [41]. Scholars have also explored some moderating factors in an attempt to address the inconsistent findings. For example, Nan and Heo [10] found that the positive relationship between cause-brand fit and individuals' attitudes toward a company was only tenable among people with high brand consciousness. For those who had low brand consciousness, cause-brand fit did not exert any impact on evaluation of the brand.

In today's market, consumer cynicism is growing such that the low fit effect driven by the inconsistent cue is more likely to be salient, with individuals being vigilant about a corporate's marketing practice [33]. However, high cause-brand fit might also evoke skepticism and the undesirable outcomes were most evident for corporates with negative images [42]. Following this context, establishing a partnership with NPOs sharing extremely similar causes may not always be a good idea. The effect of cause-brand fit may depend on pre-existing company images.

Although the findings in relation to cause-brand fit can be conditional, a meta-analysis revealed that its impacts on some response variables are in general positive, with the effect sizes being medium to large [43]. Based on the literature, the present study proposes the following hypotheses:

Hypotheses 1 (H1). Cause-brand fit will be positively associated with corporate image.

Hypotheses 2 (H2). Cause-brand fit will be positively associated with purchase intentions.

\subsection{Overall Relationship Among CRM, Corporate Image, and Purchase Intention}

As suggested earlier, corporate image refers to a mental perception of a company (i.e., the immediate picture that comes to one's mind when one sees or hears the company's name or logo) [44]. Researchers have suggested that CRM, as a strategic goal, can emotionally and mentally engage individuals with the corporation, leading to positive corporate images $[45,46]$. A positive corporate image is considered the foundation for corporate success, as it can generate product sales, attract investors, create customer loyalty, and achieve competitive advantages [45,47]. Past research has also demonstrated the significantly positive relationship between a corporate image and purchase intentions or behaviors [48]. The more favorable corporate images people perceive, the more likely they are to positively evaluate a product or service offered by that corporation, and, thus, to have positive purchase intentions. In addition, given the abovementioned positive outcome of the impact of cause-brand fit on purchase intention [32,33], the following hypothesis is, therefore, formulated:

Hypotheses 3 (H3). Corporate image will mediate the effect of cause-brand fit on purchase intentions. 


\subsection{The Role of Environmental Values}

Many CRM programs include measures with which to improve the degrading natural environment. For example, Starbucks launched a CRM initiative that aimed to reduce its environmental impact, including measures with which to reduce energy and water consumption, reduce waste, purchase renewable energy credits, and build energy-efficient stores [49]. Thus, the effectiveness of CRM campaigns may be contingent upon individuals' environmental values.

According to the schema congruence framework, people interpret incoming information based on their pre-existing schemas. Thus, people may make sense of a CRM program based on the extent to which they care about the environment; a CRM program with environmental causes may have a stronger effect on people who emphasize the need for balance between the human species and nature.

The effect of environmental values may also be understood in the context of cause involvement, which refers to how much a person relates himself or herself to the cause promoted by a company. The level of involvement or relevance one may feel is closely associated with values, past experiences, and self-concept [50]. People's level of involvement in a cause could influence the intensity with which they will process, for example, a charity marketing message [51]. Research has indicated that a company's environmental performance matters more for individuals holding stronger pro-environmental attitudes [52], suggesting a potential moderating role for environmental values.

Based on this reasoning, those who have strong environmental values may feel more connected with CRM that feature the environment, resulting in more elaborated processing and more positive attitudes [50]. Therefore, we propose the following hypotheses:

Hypotheses 4 (H4). The effect of cause-brand fit on corporate image will be stronger for people with high environmental values, as opposed to people with low environmental values.

Hypotheses 5 (H5). The effect of cause-brand fit on purchase intentions will be stronger for people with high environmental values, as opposed to people with low environmental values.

\subsection{The Moderating Role of Product Type}

While past research has revealed positive relationships between cause-brand fit and brand image as well as purchase intentions, the effects may be more salient when product type is considered [53]. Products can be classified as primarily hedonic or utilitarian, based on the relative salience of their attributes [54]. Hedonic products are multisensory and provide affective and sensual consumption experiences, whereas the consumption of utilitarian products is more cognitively driven and is intended to meet instrumental and functional needs [55]. People use distinct psychological processes when evaluating hedonic and utilitarian products [56]; they tend to focus primarily on the objective, tangible attributes of utilitarian products but engage in more subjective processing for hedonic products.

Given that the consumption of hedonic products is generally harder to justify, leading to heightened guilt, CRM can alleviate individuals' emotional ambivalence and, thus, facilitate a hedonic purchase decision [33]. Researchers have also revealed that high causebrand fit can reduce individuals' feelings of guilt when purchasing hedonic products [57]. In keeping with the literature, the effect of CRM on purchase intention may be stronger for hedonic products, as opposed to utilitarian products. The current study, therefore, proposes the following hypothesis:

Hypotheses 6 (H6). The effect of cause-brand fit on corporate image and purchase intention will be stronger for hedonic products than for utilitarian products.

So far, the literature and theories have been sufficient in informing the formulation of our hypotheses. However, they are less thorough and consistent about the role of product types in affecting the more complicated moderation and mediation relationship among all other variables. Therefore, in the following sections, we will introduce literature that will serve as foundations for the development of the research questions. 
Research has shown that, when people are purchasing hedonic products, they are more likely to experience emotions such as pleasure or guilt, and these emotions can increase their likelihood of engaging in charitable activities [13]. In other words, when it comes to hedonic products, individuals may pay more attention to the CRM component, as well as to the company that sponsors the cause. In contrast, when purchasing utilitarian products, the CRM campaigns and the positive corporate image generated by the cause may be less effective in shaping people's purchasing decisions.

However, it is unclear whether CRM can always lead to positive direct and indirect effects on purchase intention for hedonic products. Research suggests that, when the product and the cause do not fit, people may be skeptical of the real motive of the company, which will not help build up the reputation of the company or increase people's purchase intentions. Based on the literature, the present study proposes the following research question:

RQ1: Do the indirect effects of cause-brand fit on purchase intention through corporate image vary with product type?

Literature about product symbolism suggests that the use of certain products or brands reflects personalities [58]. Those who hold high environmental values are more likely to identify themselves with companies dedicated to an environmental cause than are people who care less about the environment. Integrating the idea of product type, it is likely that the moderation of environmental values will not be significant for hedonic products, because the guilt generated from purchasing frivolous products can be experienced both by people with high and with low environmental values. In contrast, environmental values may moderate the effect of cause-brand fit on purchase intentions when it comes to utilitarian products. Because relevant research is scant, especially in relation to corporate image, the present study proposes the following research question:

RQ2: Do the moderating effects of environmental values on corporate image and purchase intentions vary with product type?

The research framework is illustrated in Figure 1.

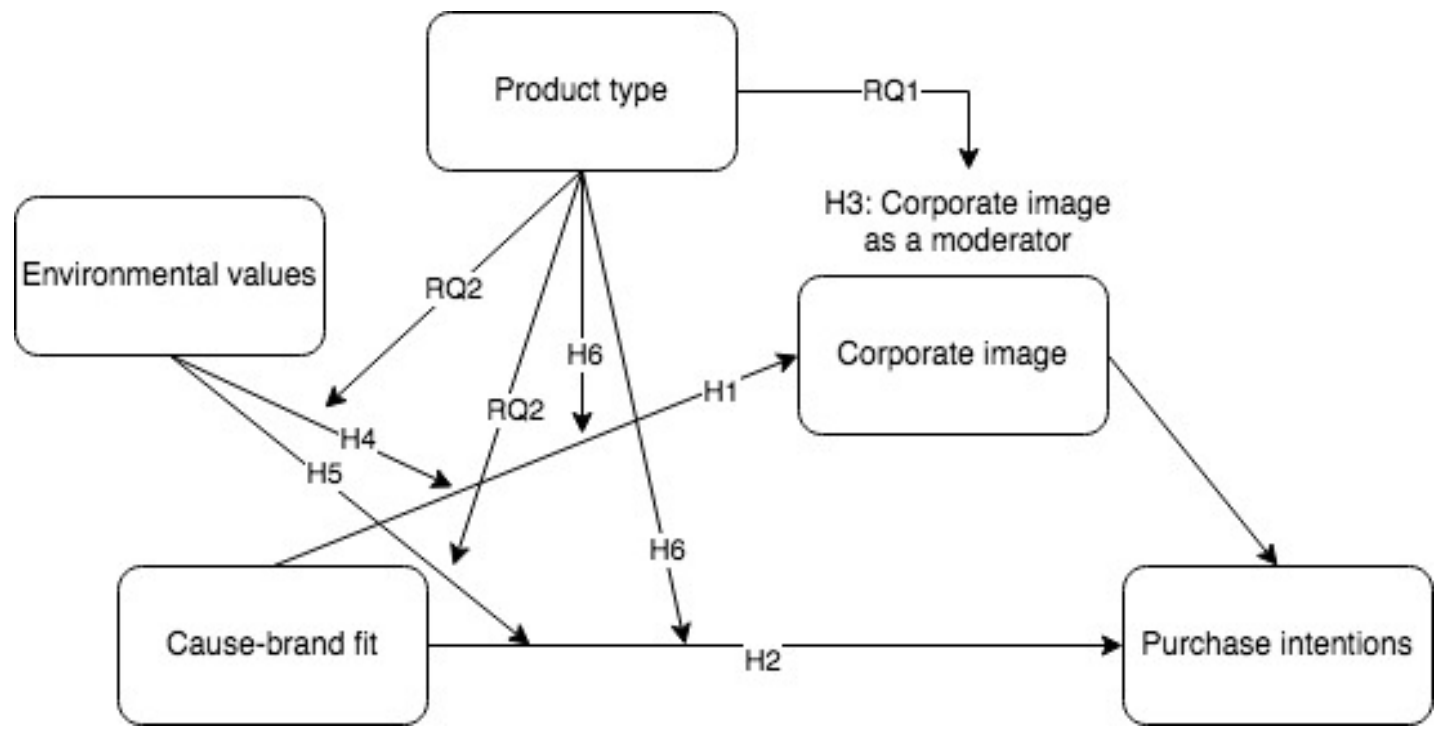

Figure 1. Research model.

\section{Methods}

\subsection{Research Design}

This study conducted a between-subject experiment with eight experimental groups $(4 \times 2)$. The experimental scenarios involved the levels of fit between the purpose of the CRM campaigns and the telecommunications company. As such, three experimental groups (i.e., high-fit, medium-fit, and low-fit) and one control group (i.e., only product/service 
information) were comprised in this study. In the experimental conditions, the company promised to donate three percent of the revenues to the selected NPOs for every iPhone sold in the hedonic product condition and for every Internet service subscription in the utilitarian product condition. In the control condition, only promotion for either the iPhone 11 Pro (a hedonic product) or 4G Internet service (a utilitarian service) were featured.

In addition, to avoid eliciting strong feelings from the participants that may bias the results of our experiment, we chose a fictitious company-Taiwan Broadband, as the subject of the CRM campaign. The choice of an unknown company was consistent with the practice of many previous studies (e.g., [59]).

\subsection{Stimulus Materials and Pretest}

In order to determine the environmental NPOs and product type for the stimuli, this study conducted a pretest from 8 September to 10 September 2019, with a convenient sample of 105 people. Of the pretest participants, $76.2 \%$ were female and the mean age of the sample was $31.77(S D=11.10)$.

We asked the participants a battery of questions about whether they considered it a good fit if Taiwan Broadband is planning to partner with the NPOs. We adapted items from the work of Fortin et al. [60] and Speed and Thompson [61]. The variables were as follows: (1) "There is a logical connection between the NPO and the telecommunications company" and (2) "It makes sense to me that this company and the NPO cooperate." We combined the two variables to form a scale. The results suggested that the International Electromagnetic Fields Alliance (IEMFA), the Green Web Foundation (GWF), and the United Nations World Food Programme (WFP) represent organizations with distinctly different levels of cause-brand fit.

To distinguish the hedonic and utilitarian attributes of products, we asked the respondents to rate the products with a pair of semantically contrasting phrases. Respondents indicated the extent to which an iPhone and $4 \mathrm{G}$ Internet service were utilitarian or hedonic. A higher score indicated a higher level of hedonism. We chose the iPhone 11 Pro as an example of a hedonic product because an Apple smartphone is very popular in Taiwan, especially among young adults [62]. On the other hand, we chose 4G Internet service as an example of a utilitarian good. Based on a representative survey of Taiwanese Internet use behavior [63], 77\% of those who accessed the Internet through wireless connection used $4 \mathrm{G}$ services, suggesting that $4 \mathrm{G}$ mobile connectivity has become a commodity in people's everyday life. The results of a paired-samples $t$-test showed that the participants differentiated between the iPhone and $4 \mathrm{G}$ service in terms of hedonism $(t[1174]=42.26$, $p<0.01)$. The participants perceived the iPhone as more hedonic $(M=4.81, S D=1.71)$ and the $4 \mathrm{G}$ service $(M=2.20, S D=1.41)$ as more utilitarian.

\subsection{Participants and Procedure of the Experiment}

Recruitment advertisements were placed on several Facebook pages of research participation panels and electronic bulletin boards in Taiwan. Individuals who were 20 years and older were invited and they participated in the experiment in exchange for a chance to win a lottery and received cash prizes. All of the participants were randomly assigned to one of the eight conditions. Each of the participants responded to questions about environmental values, followed by exposure to one of the eight versions of the CRM promotional materials, which included the donation claim, names of the company and the partnered NPO, the logo of the NPO, the price of the iPhone 11 Pro or $4 \mathrm{G}$ service, and an image representing the cause of the NPO. The participants then answered questions about variables related to corporate image and purchase intentions.

The online experiment was carried out from 26 September to 6 October 2019. In the questionnaire, we included filtering questions to make sure that all participants paid sufficient attention to the ads. Specifically, we asked participants whether the telecommunications company had an NPO partner based on the CRM promotional materials they just saw, and we removed participants who gave the wrong answer. The final sample size was 
1175 , of which the number of males $(\mathrm{N}=587,50 \%)$ was similar to that of females $(\mathrm{N}=588$, $50 \%)$, and the mean age was 24.71 years $(S D=8.31)$.

The majority of the participants had a college degree $(64.9 \%)$, and about one in four had a post-graduate degree (25.4\%). Despite the high education level of the sample, the average monthly salary was low, with three-fourths of them (73.4\%) earning less than $\$ 25,000$ NT (about $\$ 800$ USD), suggesting the majority of our participants may be young adults early in their career path. Although most of our participants were young and not particularly wealthy, the iPhone was not just an aspirational product for them. A survey indicated that about half of the people in Taiwan between 20 and 29 owned an iOS smartphone despite its high price [62]. The demographic features of our participants suggested that our sample to a certain extent can reflect the characteristics of the population who were more likely to consider an iOS smartphone when making purchase decisions.

\subsection{Dependent Variable}

Purchase intentions were measured by four items. Respondents indicated how much they agreed with the following statements on a seven-point scale: (1) "I would consider buying the advertised iPhone," (2) "Even if there are other options, I would prefer to purchase the advertised iPhone," (3) "I am likely to purchase the advertised iPhone," and (4) "I will recommend the advertised iPhone to my friends." The responses were summed and averaged to form a scale, with larger values indicating a higher level of intention to purchase the product shown in the advertisement $(M=3.49, S D=1.53, \alpha=0.94)$.

\subsection{Mediating and Moderating Variables}

Corporate image was measured by variables adapted from Riordan et al. [64]. Respondents were asked how much they agree with the following six statements on a seven-point scale: (1) "Generally, I think the company has a good image in society," (2) "Generally, I think the company has a good image in the industry," (3) "Generally, I think the company is actively involved in society," (4) "Generally, I think the company has a good overall image," (5) "Generally, I think the company is a good place to work," and (6) "Generally I think the company has a good image among its customers." The responses were summed and averaged to form a scale, with larger values indicating a more positive company image $(M=4.53, S D=0.93, \alpha=0.92)$.

Environmental values were measured by five variables adapted from the 15-item New Ecological Paradigm [65]. Respondents indicated how much they agreed with the following statements on a seven-point scale: (1) "When humans interfere with nature, it often produces disastrous consequences," (2) "Humans are severely abusing the environment," (3) "Despite our special abilities, humans are still subject to the laws of nature," (4) "The balance of nature is very delicate and easily upset," and (5) "If things continue on their present course, we will soon experience a major ecological catastrophe." The responses were summed and averaged to form the environmental values scale, with larger values indicating a higher level of appreciation for the environment $(M=6.21, S D=0.78, \alpha=0.87)$.

\section{Results}

\subsection{Manipulation Check}

We checked for manipulation of the fit between the NPO and the telecommunications company. The results of an ANOVA test showed that people perceived the three NPOs differently in terms of fit with the telecommunications company $(\mathrm{F}[2,943]=156.60, p<0.01)$. The participants perceived the IEMFA $(M=4.56, S D=1.19)$ as having the highest fit with the Taiwan Broadband, followed by the GWF $(M=4.32, S D=1.21)$ and the WFP $(M=3.04$, $S D=1.18)$. It is noteworthy that the IEMFA and the GWF were marginally different in their level of fit with the Taiwan Broadband $(p<0.10)$.

We used the perceived hedonic level to check whether participants could differentiate between the two products. The results of a paired-samples $t$-test showed that the participants differentiated between the iPhone and $4 \mathrm{G}$ service in terms of hedonism 
$(t[1174]=42.26, p<0.01)$. The participants perceived the iPhone as more hedonic $(M=4.81$, $S D=1.71)$ and the $4 \mathrm{G}$ service $(M=2.20, S D=1.41)$ as more utilitarian.

Studies have indicated that familiarity not only was positively related to product or brand attitudes, but also strengthened the effects of CRM on product evaluation $[66,67]$. We, therefore, measured the level of familiarity on a seven-point scale to ensure that people were not familiar with Taiwan Broadband, the fictitious company created in this study $(M=2.90, S D=1.56)$.

Although we have eliminated the potential impact of company familiarity, individuals' purchase intentions may increase or decrease due to their attitudes toward the advertised product. We, therefore, tested participants' preferences toward the iPhone in order to rule out the impact of the potential bias when exposed to brand information. Participants indicated how much they agreed with three statements [68] on a seven-point scale: (1) "Although another brand has the same features as iPhone, I would prefer to purchase iPhone," (2) "If another brand does not differ from iPhone, it seems smarter to purchase iPhone," and (3) "Although there is another brand as good as iPhone, I prefer to buy iPhone." The results of indicated that the participants held a neutral attitude toward the iPhone $(M=4.15, S D=1.94, \alpha=0.95)$.

\subsection{Hypotheses Testing and Research Questions}

H1 stipulated a positive relationship between cause-brand fit and corporate image. The results showed that cause-brand fit exerted a positive effect on corporate image $(F[3,1167]=5.49 ; p<0.01)$, as indicated in Table 1 . Post-hoc analysis indicated that the mean of the control group $(M=4.32)$ was significantly lower than that of two experimental conditions. Specifically, those exposed to pure ads gave the company a lower evaluation than did those in the low fit condition $\left(M_{W F P}=4.57\right)$ and medium fit condition $\left(M_{G W F}=4.63\right)$. The difference between the control group and the high fit condition $\left(M_{I E M F A}=4.44\right)$ was only marginally significant. Participants in the three experimental conditions did not differ in their corporate image evaluations. H1 is, therefore, partially supported.

H2 proposed a positive relationship between the cause-brand fit and purchase intentions. The results in Table 1 showed that the cause-brand fit exerted a positive effect on purchase intentions $(F[3,1167]=3.61 ; p<0.05)$. Post-hoc analysis indicated that the mean of the control group $(M=3.28)$ was significantly lower than that of the medium fit conditions $\left(M_{G W F}=3.67\right)$. Participants in the three experimental conditions did not differ in terms of their purchase intentions. $\mathrm{H} 2$ is, therefore, partially supported.

Table 1. ANOVA analysis.

\begin{tabular}{ccccccccc}
\hline & \multicolumn{3}{c}{ Corporate Image } & \multicolumn{4}{c}{ Purchase Intentions } \\
\cline { 2 - 9 } & $d f$ & $\boldsymbol{F}$ & $\boldsymbol{P}$ & $\boldsymbol{\eta}^{\mathbf{2}}$ & $\boldsymbol{D f}$ & $\boldsymbol{F}$ & $\boldsymbol{p}$ & $\boldsymbol{\eta}^{\mathbf{2}}$ \\
\hline Cause-brand fit & 3 & 5.49 & 0.00 & 0.01 & 3 & 3.61 & 0.01 & 0.01 \\
Product type & 1 & 2.52 & 0.18 & 0.02 & 1 & 2.19 & 0.00 & 0.02 \\
Fit $\times$ type & 3 & 0.42 & 0.74 & 0.00 & 3 & 1.39 & 0.25 & 0.00 \\
Error & 1167 & & & & 1167 & & & \\
Total & 1175 & & & & 1175 & & & \\
\hline
\end{tabular}

H3 posited that corporate image will mediate the effect of the cause-brand fit on purchase intentions. Regression analysis showed that the three experimental conditions exerted significant impacts on corporate image and corporate image was associated with purchase intentions (Table 2). To further test the indirect relationship, we employed the PROCESS macro developed by Hayes [69]. The results showed that the indirect effect of the cause-brand fit on purchase intentions through corporate image was statistically significant $\left(\beta_{\mathrm{WFP}}=0.18,95 \%\right.$ BootCI $=0.0611-0.2909 ; \beta_{\mathrm{IEMFA}}=0.15,95 \%$ BootCI $=0.0303-0.2722$; $\beta_{\mathrm{GWF}}=0.22,95 \%$ BootCI $\left.=0.0963-0.3468\right)$. After we took into account the concept of corporate image, the direct effect of the cause-brand fit disappeared, regardless of the 
level of fit. H3 is, therefore, supported. Further analysis indicated that the participants in all the experimental groups developed a more positive corporate image, which in turn increased their intentions to purchase the product or subscribe to the service. However, the experimental groups did not differ in terms of indirect effects on purchase intentions.

Table 2. Regression analysis predicting corporate image and purchase intentions.

\begin{tabular}{ccccc}
\hline & DV = Corporate Image & \multicolumn{2}{c}{ DV = Purchase Intention } \\
\hline & $\begin{array}{c}\text { Unstandardized } \\
\text { coefficient }\end{array}$ & $p$ & $\begin{array}{c}\text { Unstandardized } \\
\text { coefficient }\end{array}$ & $p$ \\
WFP & $0.25(0.08)$ & 0.00 & $0.08(0.12)$ & 0.48 \\
GWF & $0.31(0.08)$ & 0.00 & $0.16(0.12)$ & 0.19 \\
IEMFA & $0.21(0.08)$ & 0.01 & $-0.06(0.12)$ & 0.63 \\
Product type & $-0.09(0.05)$ & 0.10 & $-0.35(0.08)$ & 0.00 \\
(hedonic product $=1)$ & & & $0.70(0.04)$ & 0.00 \\
Corporate image & &
\end{tabular}

H4 stated that the effect of the cause-brand fit on corporate image would vary based on people's environmental values. To test the H4, we used Model 8 of the PROCESS macro. This model allowed us to simultaneously test two moderation effects: the relationship between the cause-brand fit and corporate image and the relationship between the cause-brand fit and purchase intentions. The results showed that the interactions between environmental values and all three experimental conditions were statistically significant $\left(\beta_{\mathrm{WFP} \times \mathrm{EV}}=0.22, p<0.05 ; \beta_{\mathrm{IEMFA} \times \mathrm{EV}}=0.29, p<0.01 ; \beta_{\mathrm{GWF} \times \mathrm{EV}}=0.30, p<0.01\right)$. Specifically, the effects of CRM initiatives were not significant (i.e., there was no difference between the experimental conditions and control groups) for participants with low environmental values. In contrast, when participants' environmental values were high, those in the experimental groups perceived a better corporate image than did those in the pure advertisement groups. $\mathrm{H} 4$ is, therefore, supported.

H5 stated that the effect of the cause-brand fit on purchase intentions would vary based on people's environmental values. The results indicated that the interaction between the IEMFA condition and environmental values was statistically significant $\left(\beta_{\text {IEMFA }} \times \mathrm{EV}=0.38\right.$, $p<0.05)$. Specifically, the purchase intentions of participants with low environmental values decreased after exposure to the advertisement in which the IEMFA was a partner $\left(\beta_{\text {IEMFA }}=-0.37, p<0.05\right)$. In contrast, the CRM involving the IEMFA did not exert any impact on purchase intentions for participants with high environmental values $\left(\beta_{\text {IEMFA }}=0.23\right.$, $p>0.05)$. H5 is, therefore, partially supported.

The findings also revealed statistically significant, moderated mediation effects. Environmental values moderated the indirect effect of the cause-brand fit on purchase intentions through corporate image. The indirect effect of the cause-brand fit became stronger as people's environmental values increased, as suggested by the positive values of the indices in Table 3.

Table 3. Indices of moderated mediation.

\begin{tabular}{ccccc}
\hline Conditions & Index & BootSE & BootLLCI & BootULCI \\
\hline WFP vs. control & 0.16 & 0.08 & 0.01 & 0.32 \\
GWF vs. control & 0.21 & 0.08 & 0.05 & 0.38 \\
IEMFA vs. control & 0.20 & 0.09 & 0.04 & 0.38 \\
\hline
\end{tabular}

Note. Values are unstandardized regression coefficients.

H6 posited that the effect of cause-brand fit on corporate image and purchase intention will vary with product type. The ANOVA results showed that product type failed to serve as a moderator for either corporate image or purchase intentions (see Table 1). H6 is, therefore, not supported. 
RQ1 examined whether the effects of cause-brand fit on purchase intention through corporate image vary with product type. Based on Model 4, the results showed that corporate image positively mediated the effects of cause-brand fit on purchase intentions in all experimental conditions involving the utilitarian product (see Table 4). However, the indirect effect was not significant for the IEMFA condition with the hedonic product.

Table 4. Indirect effects of CRM by product type.

\begin{tabular}{ccccc}
\hline Conditions & Effect & BootSE & BootLLCI & BootULCI \\
\hline Hedonic product (i.e., iPhone) & & & & \\
WFP & 0.13 & 0.06 & 0.01 & 0.26 \\
GWF & 0.17 & 0.07 & 0.05 & 0.33 \\
IEMFA & 0.07 & 0.07 & -0.05 & 0.21 \\
service) & & & & \\
WFP & 0.22 & 0.11 & 0.01 & 0.43 \\
GWF & 0.26 & 0.11 & 0.05 & 0.47 \\
IEMFA & 0.23 & 0.11 & 0.03 & 0.44 \\
\hline
\end{tabular}

Note. Values in the effect column are unstandardized regression coefficients.

RQ2 examined whether the moderating effects of environmental values on corporate image and purchase intentions vary with product type. This study observed different patterns for the two kinds of products. Environmental values moderated the effects of $\mathrm{WFP}\left(\beta_{\mathrm{WFP} \times \mathrm{EV}}=0.32, p<0.05\right)$ and GWF $\left(\beta_{\mathrm{GWF} \times \mathrm{EV}}=0.48, p<0.01\right)$ on corporate image for the hedonic product, but none of the interaction terms for the necessary product were significant $\left(\beta_{\mathrm{WFP} \times \mathrm{EV}}=0.13, p>0.05 ; \beta_{\mathrm{IEMFA} \times \mathrm{EV}}=0.29, p>0.05 ; \beta_{\mathrm{GWF} \times \mathrm{EV}}=0.16, p>0.05\right)$. The moderating patterns were also different in terms of purchase intentions. Environmental values moderated IEMFA when the product was necessary $\left(\beta_{\text {IEMFA } \times \text { EV }}=0.47, p<0.05\right.$, but did not moderate any of the CRM groups when the product was hedonic. In addition, environmental values did not moderate the indirect effect in the IEMFA condition if the product under consideration was hedonic. In the other two conditions, the positive indirect effects of CRM became stronger when people's environmental values increased. However, for the utilitarian product, in all three CRM conditions, the indirect effects were not moderated by environmental values.

\section{Discussion}

The present study examined the effects of CRM campaigns with different levels of cause-brand fit. The results of a $4 \times 2$ online experiment showed that cause-brand fit were significantly related to perceived corporate image and purchase intentions. Moreover, we found that corporate image mediated the effect of CRM campaigns on purchase intentions. The results suggest that, in general, applying a CRM strategy may help a company to build a more positive reputation and to boost sales of its products.

The levels of cause-brand fit failed to exhibit any effect, which is different from some previous research findings and the concept of congruity. However, our findings are in line with other findings in the literature, which suggest that environmental causes are more effective than efforts targeting other causes (e.g., economic or social) for the high-tech industry or products [70]. Therefore, people tended to respond positively as long as the company showed certain concern over the environment; rendering fit a less relevant factor.

It is also likely that the three NPOs were not different enough to produce effects. Although the participants were able to differentiate between the three organizations in terms of their level of fit, the mean values were close to the middle point (i.e., four on a seven-point scale), suggesting that all three NPOs had at least a moderate level of fit with the telecommunications industry.

The present study did not find evidence that the effect of cause-brand fit on corporate image and purchase intentions varied by product type. In other words, the positive effects of cause-brand fit on corporate image and purchase intentions were similar for 
utilitarian products (in this study, 4G Internet service) and hedonic products (in this study, the iPhone 11 Pro). This may be attributable to the magnitude of the donation (i.e., three percent). Previous research has indicated that large donations to a charity more effectively promote hedonic products than utilitarian products [71]. In the present study, we included two variables asking the participants whether this magnitude was reasonable. The mean of the two variables combined was $4.84(S D=1.13)$ on a seven-point scale, suggesting that people were not extremely satisfied with the magnitude of the donation promised by the company. Therefore, cause-brand fit exerted a similar effect on perceived corporate image and purchase intentions for both types of products.

In addition to the main effect, this study identified a subtler dynamic relationship between cause-brand fit and environmental values. We found that cause-brand fit exerted a more pronounced impact on corporate image if people's environmental values were high, which was consistent with existing research [52] and supports the notion that the effects of the CRM initiative were conditional rather than universal.

However, environmental values did not amplify the effect of cause-brand fit on purchase intention. These results seem to suggest that the benefits of CRM may not be completely transferrable from perception to purchase intention, even if the cause fits people's dispositional preferences for a better environment.

Before we discuss the contributions of this study, it is necessary to mention some caveats that may influence the interpretation of our results. First, the difference in causebrand fit between the three experimental groups was not prominent enough, although the mean difference was statistically significant. Future research could explore different sets of NPOs to determine whether our results can be verified. In addition, our study examined the effect of CRM on individuals' responses using global NPOs. Future studies could compare global and local NPOs to explore how the physical and psychological proximity of NPOs affect individuals' attitudes and behaviors. Third, our study explored purchase intentions regarding a $4 \mathrm{G}$ Internet service and the new iPhone because Internet services and mobile devices are two major sources of revenue for the telecom industry in the consumer market. Future research could consider distinguishing between products in different categories, such as tangible and intangible or experiential and material [72], to improve the understanding of the phenomenon. Finally, participants of this study were exposed to the CRM campaigns only one time. This artificial control was different from the real-life scenario in which people may see the same advertisements multiple times and on various media platforms. Nonetheless, this study still observed pronounced direct and indirect effects of cause-brand fit. The impact of the cause-brand fit may even be stronger if the individuals are exposed to it in an extended period of time or more intensively [73].

\section{Conclusions}

It is increasingly common for companies to partner with NPOs in order to generate profits for economic prosperity while simultaneously striving for environmental sustainability to fulfill their responsibilities to society. Linking advertisement characteristics and individual predispositional factors, the present study examined the effect of cause-brand fit, as well as the role of product type and environmental values as moderators, on perceived corporate image and purchase intentions. By doing so, this study directly responded to the calls for more research on environmental or green advertising or campaigns $[6,74]$ and contributed to the existing literature on sustainability by highlighting people's responses to environmental initiatives. In an era when individuals are conscious about the balance between a company's profit-making activities and environmental responsibility, it is especially meaningful to understand the conditions in which CRM are effective.

The results of the present study indicate whether a CRM strategy applied by a telecommunications company was a more important factor than what kind of CRM initiative was implemented. As current research has not yet agreed upon the effects of CRM, some companies are hesitant about applying such initiatives. The results of this study corroborated 
the usefulness of CRM and may serve as positive evidence that encourages companies to be more socially responsible.

Furthermore, previous studies often employed causes from different areas in their manipulation of the cause-brand fit (e.g., healthy diet vs. traffic safety in Nan and Heo's study [10]). The present study extended the stream of research in CRM by examining the effect of fit within the same cause area (i.e., various environmental causes). In contrast to studies that found cause-brand fit moderated the effects of CRM on purchase intentions of hedonic products [57], our study did not find such a relationship. Our results attest to the importance of paying attention to the nature of causes because they may serve as different bases of comparison and affect subsequent findings.

More importantly, the present study found that an environmental CRM is only useful for people who care highly about the environment, suggesting that appealing to environmental causes is not a panacea for companies by which to increase reputation or sales. As there is a lack of research in the literature about the moderating factors of CRM campaigns and marketing outcomes [66], the present study addresses the gap by identifying the groups for whom an environmental CRM is more effective.

The present study also provided a granular look at the congruence theory. Previous studies have suggested that people tend to make decisions that are consistent with their pre-existing knowledge. In the context of this study, we hypothesized that, if the CRM cause was not perceived to be congruent with the nature of the company, it was possible that people would not be affected by the CRM program. However, our results suggested that congruency may be conditional. For people with low environmental values, purchase intentions decreased after exposure to the CRM initiatives featuring the IEMFA (i.e., the high fit organization) as a partner. By contrast, the CRM involving the IEMFA did not exert any impact on the purchase intentions of people with high environmental values. A practical implication of the findings is that CRM campaigns may be counterproductive even if the brand and the cooperating organization fit each other well. The results also suggest that the effect of cause-brand fit may depend on individuals' value predispositions (e.g., environmental values).

This study also shed light on CRM campaigns for hedonic goods. Previous research has shown that hedonically oriented campaigns strengthen people's attitudes regarding charitable organizations. However, the present study found that the effects (including the direct and indirect effects) of an environmentally directed CRM were similar for utilitarian products and for hedonic products. Therefore, brands selling hedonic products may want to evaluate the consequences of CRM strategies more carefully before employing them. An environmental CRM promoting hedonic products may be more effective in shaping the purchase intentions of those who held strong environmental values.

This study provides insights for new telecommunications companies that aim to enter the market. In Taiwan, although the telecommunications market is dominated by three major companies, some smaller companies have emerged. Our results show that these new companies can employ environmental CRM strategies to boost their company reputations.

Last but not least, some researchers have defined CSR as the conformity of a company to stakeholders' norms, which can be culturally variant. To the extent that most research examining the effects of CRM was from the Western world, the present study looked into how CRM was employed in Taiwan, where the general public has a relatively high level of environmental concerns. Therefore, the present study has extended the geographic scope of sustainable marketing strategy and its implementation.

Author Contributions: Conceptualization, T.S.; methodology, T.S. and S.S.W.; validation, T.S.; formal analysis, T.S.; resources, S.S.W.; data curation, T.S. and S.S.W.; writing-original draft preparation, T.S. and S.S.W.; writing-review and editing, T.S.; visualization, T.S.; funding acquisition, S.S.W. All authors have read and agreed to the published version of the manuscript. 
Funding: This work was financially supported by the Intelligent Electronic Commerce Research Center from The Featured Areas Research Center Program within the framework of the Higher Education Sprout Project by the Ministry of Education (MOE) in Taiwan.

Institutional Review Board Statement: This study did not collect identifying details (names, dates of birth, identity numbers and other information) of the participants and the data collected will be used in aggregate form only. The information was provided for the participants before they decided to take part in the study. "All procedures performed in studies involving human participants were in accordance with the ethical standards of the institutional and/or national research committee and with the 1964 Helsinki declaration and its later amendments or comparable ethical standards.

Informed Consent Statement: Informed consent was obtained from all participants involved in the study.

Data Availability Statement: Due to privacy and ethical concerns, the data are not publicly available.

Conflicts of Interest: The authors declare no conflict of interest.

\section{References}

1. Buhmann, K.; Jonsson, J.; Fisker, M. Do no harm and do more good too: Connecting the SDGs with business and human rights and political CSR theory. Corp. Gov. 2019, 19, 309-403. [CrossRef]

2. Buhmann, K. Future perspectives: Doing good but avoiding SDG-washing. Creating relevant societal value without causing harm. In OECD Guidelines for Multinational Enterprises: A Glass Half Full; Mulder, H., Voort, S.V., Eds.; OECD: Paris, France; Nyenrode Business University: Nyenrode, Poland, 2018; pp. 127-134.

3. Grimmer, M.; Woolley, M. Green marketing messages and consumers' purchase intentions: Promoting personal versus environmental benefits. J. Mark. Commun. 2014, 20, 231-250. [CrossRef]

4. Lee, K.-H.; Shin, D. Consumers' responses to CSR activities: The linkage between increased awareness and purchase intention. Public Relat. Rev. 2010, 36, 193-195. [CrossRef]

5. Grimmer, M.; Bingham, T. Company environmental performance and consumer purchase intentions. J. Bus. Res. 2013, 66, 1945-1953. [CrossRef]

6. Taylor, C.R. A call for more research on 'green' or environmental advertising. Int. J. Advert. 2015, 34, 573-575. [CrossRef]

7. Lafferty, B.A. The relevance of fit in a cause-brand alliance when consumers evaluate corporate credibility. J. Bus. Res. 2007, 60, 447-453. [CrossRef]

8. Chéron, E.; Kohlbacher, F.; Kusuma, K. The effects of brand cause fit and campaign duration on consumer perception of cause-related marketing in Japan. J. Consum. Mark. 2012, 29, 357-368. [CrossRef]

9. Melero, I.; Montaner, T. Cause-related marketing: An experimental study about how the product type and the perceived fit may influence the consumer response. Eur. J. Manag. Bus. Econ. 2016, 25, 161-167. [CrossRef]

10. Nan, X.; Heo, K. Consumer responses to corporate social responsibility (CSR) initiatives: Examining the role of brand-cause fit in cause-related marketing. J. Advert. 2007, 36, 63-74. [CrossRef]

11. Stern, P.C.; Dietz, T. The value basis of environmental concern. J. Soc. Issues 1994, 50, 65-84. [CrossRef]

12. Stern, P. Toward a coherent theory of environmentally significant behavior. J. Soc. Issues 2000, 56, 407-424. [CrossRef]

13. Strahilevitz, M.; Myers, J.G. Donations to charity as purchase incentives: How well they work may depend on what you are trying to sell. J. Consum. Res. 1998, 24, 434-446. [CrossRef]

14. Ghingold, M. Guilt arousing communications: An unexplored variable. In Advances in Consumer Research; Monroe, K., Ed.; Association of Consumer Research: Ann Arbor, MI, USA, 1981; Volume 8, pp. 442-448.

15. Lerro, M.; Raimondo, M.; Stanco, M.; Nazzaro, C.; Marotta, G. Cause Related Marketing among Millennial Consumers: The Role of Trust and Loyalty in the Food Industry. Sustainability 2019, 11, 535. [CrossRef]

16. Varadarajan, P.R.; Menon, A. Cause-related marketing: A coalignment of marketing strategy and corporate philanthropy. J. Mark. Manag. 1988, 52, 58-74. [CrossRef]

17. Brønn, P.; Vrioni, A. Corporate social responsibility and cause-related marketing: An overview. Int. J. Advert. 2001, 20, 207-222. [CrossRef]

18. Andreasen, A.R. Profits for nonprofits: Find a corporate partner. Harv. Bus. Rev. 1996, 74, 47-50.

19. Brown, T.J.; Dacin, P.A. The company and the product: Corporate associations and consumer product responses. J. Mark. 1997, 61, 68-84. [CrossRef]

20. He, Y.; Lai, K.K. The effect of corporate social responsibility on brand loyalty: The mediating role of brand image. Total. Qual. Manag. Bus. Excel. 2014, 25, 249-263. [CrossRef]

21. Van Riel, C.B.; Fombrun, C.J. Essentials of Corporate Communication: Implementing Practices for Effective Reputation Management; Routledge: New York, NY, USA, 2007; p. 40.

22. Chang, C.-P. The relationships among corporate social responsibility, corporate image and economic performance of high-tech industries in Taiwan. Qual Quant. 2009, 43, 417-429. [CrossRef] 
23. Martínez, P.; del Bosque, I.R. Explaining Consumer Behavior in the Hospitality Industry: CSR Associations and Corporate Image. In Handbook of Research on Global Hospitality and Tourism Management; IGI Global: Hershey, PA, USA, 2015; pp. 501-519.

24. Lee, C.-Y. Does corporate social responsibility influence customer loyalty in the Taiwan insurance sector? The role of corporate image and customer satisfaction. J. Promot. Manag. 2019, 25, 43-64. [CrossRef]

25. Grewal, D.; Monroe, K.B.; Krishnan, R. The effects of price-comparison advertising on buyers' perceptions of acquisition value, transaction value, and behavioral intentions. J. Mark. 1998, 62, 46-59.

26. Ajzen, I. The theory of planned behavior. Organ. Behav. Hum. Decis. Process. 1991, 50, 179-211. [CrossRef]

27. Patel, J.D.; Gadhavi, D.D.; Shukla, Y.S. Consumers' responses to cause related marketing: Moderating influence of cause involvement and skepticism on attitude and purchase intention. Int. Rev. Public Nonprofit Mark. 2017, 14, 1-18. [CrossRef]

28. Sen, S.; Bhattacharya, C.B. Does doing good always lead to doing better? Consumer reactions to corporate social responsibility. J. Mark. Res. 2001, 38, 225-243. [CrossRef]

29. Bae, J.; Cameron, G.T. Conditioning effect of prior reputation on perception of corporate giving. Public Relat. Rev. 2006, 32, 144-150. [CrossRef]

30. Becker-Olsen, K.L.; Cudmore, B.A.; Hill, R.P. The impact of perceived corporate social responsibility on consumer behavior. J. Bus. Res. 2006, 59, 46-53. [CrossRef]

31. Menon, S.; Kahn, B.E. Corporate sponsorships of philanthropic activities: When do they impact perception of sponsor brand? J. Consum. Psychol. 2003, 13, 316-327. [CrossRef]

32. Bigné-Alcañiz, E.; Currás-Pérez, R.; Ruiz-Mafé, C.; Sanz-Blas, S. Cause-related marketing influence on consumer responses: The moderating effect of cause-brand fit. J. Mark. Commun. 2012, 18, 265-283. [CrossRef]

33. Das, N.; Guha, A.; Biswas, A.; Krishnan, B. How product-cause fit and donation quantifier interact in cause-related marketing (CRM) settings: Evidence of the cue congruency effect. Mark. Lett. 2016, 27, 295-308. [CrossRef]

34. Fishbein, M.; Ajzen, I. Belief, Attitude, Intention, and Behavior: An Introduction to Theory and Research; Addison-Wesley: Reading, MA, USA, 1975.

35. Mandler, G. The Structure of Value: Accounting for Taste. In Affect and Cognition: The 17th Annual Carnegie Symposium on Cognition; Margaret, H., Clarke, S., Fiske, S.T., Eds.; Lawrence Erlbaum: Hillsdale, NJ, USA, 1982; pp. 3-36.

36. Jurca, M.A.; Madlberger, M. Ambient advertising characteristics and schema incongruity as drivers of advertising effectiveness. J. Mark. Commun. 2015, 21, 48-64. [CrossRef]

37. Sjödin, H.; Törn, F. When communication challenges brand associations: A framework for understanding consumer responses to brand image incongruity. J. Consum. Behav. 2006, 5, 32-42. [CrossRef]

38. Harmon-Kizer, T.R. The effects of schema congruity on consumer response to celebrity advertising. J. Mark. Commun. 2017, 23, 162-175. [CrossRef]

39. Pracejus, J.W.; Olsen, G.D. The role of brand/cause fit in the effectiveness of cause-related marketing campaigns. J. Bus. Res. 2004, 57, 635-640. [CrossRef]

40. Moosmayer, D.C.; Fuljahn, A. Corporate motive and fit in cause related marketing. J. Prod. Brand. Manag. 2013, 22, 200-207. [CrossRef]

41. Lafferty, B.A. Selecting the right cause partners for the right reasons: The role of importance and fit in cause-brand alliances. Psychol. Mark. 2009, 26, 359-382. [CrossRef]

42. Yoon, Y.; Gürhan-Canli, Z.; Schwarz, N. The effect of corporate social responsibility (CSR) activities on companies with bad reputations. J. Consum. Psychol. 2006, 16, 377-390. [CrossRef]

43. Zasuwa, G. The role of company-cause fit and company involvement in consumer responses to CSR initiatives: A meta-analytic review. Sustainability 2017, 9, 1016. [CrossRef]

44. Gray, E.R.; Balmer, J.M. Managing corporate image and corporate reputation. Long Range Plann. 1998, 31, 695-702. [CrossRef]

45. Demetriou, M.; Papasolomou, I.; Vrontis, D. Cause-related marketing: Building the corporate image while supporting worthwhile causes. J. Brand. Manag. 2010, 17, 266-278. [CrossRef]

46. Vanhamme, J.; Lindgreen, A.; Reast, J.; Van Popering, N. To do well by doing good: Improving corporate image through cause-related marketing. J. Bus. Ethics 2012, 109, 259-274. [CrossRef]

47. Cornwell, T.B.; Coote, L.V. Corporate sponsorship of a cause: The role of identification in purchase intent. J. Bus. Res. 2005, 58, 268-276. [CrossRef]

48. Yadav, R.; Kumar Dokania, A.; Swaroop Pathak, G. The influence of green marketing functions in building corporate image: Evidences from hospitality industry in a developing nation. Int. J. Contemp. Hosp. Manag. 2016, 28, 2178-2196. [CrossRef]

49. Kim, Y. Consumer responses to the food industry's proactive and passive environmental CSR, factoring in price as CSR tradeoff. J. Bus. Ethics 2017, 140, 307-321. [CrossRef]

50. Grau, S.L.; Folse, J.A.G. Cause-related marketing (CRM): The influence of donation proximity and message-framing cues on the less-involved consumer. J. Advert. 2007, 36, 19-33. [CrossRef]

51. Broderick, A.; Jogi, A.; Garry, T. Tickled pink: The personal meaning of cause related marketing for customers. J. Mark. Manag. 2003, 19, 583-610. [CrossRef]

52. Bohlmann, C.; Krumbholz, L.; Zacher, H. The triple bottom line and organizational attractiveness ratings: The role of proenvironmental attitude. Corp. Soc. Responsib. Environ. Manag. 2018, 25, 912-919. [CrossRef] 
53. Chang, C.T.; Liu, H.W. Goodwill hunting? Influences of product-cause fit, product type, and donation level in cause-related marketing. Mark. Intell. Plan. 2012, 30, 634-652. [CrossRef]

54. Chernev, A. The goal-attribute compatibility in consumer choice. J. Consum. Psychol. 2004, 14, 141-150. [CrossRef]

55. Khan, U.; Dhar, R.; Wertenbroch, K. A behavioral decision theory perspective on hedonic and utilitarian choice. In Inside Consumption: Frontiers of Research on Consumer Motives, Goals, and Desires; Ratneshwar, S., Glen Mick, D., Eds.; Routledge: New York, NY, USA, 2005; Volume 1, pp. 144-165.

56. Melnyk, V.; Klein, K.; Völckner, F. The double-edged sword of foreign brand names for companies from emerging countries. J. Mark. 2012, 76, 21-37. [CrossRef]

57. Baghi, I.; Antonetti, P. High-fit charitable initiatives increase hedonic consumption through guilt reduction. Eur. J. Mark. 2017, 51, 2030-2053. [CrossRef]

58. Belk, R.W. Possessions and the extended self. J. Consum. Res. 1988, 15, 139-168. [CrossRef]

59. Singh, S.; Duque, L.C. Familiarity and format: Cause-related marketing promotions in international markets. Int. Mark. Rev. 2019, 5, 901-921. [CrossRef]

60. Fortin, D.; Uncles, M.; Carlson, J.; O'Cass, A. Managing web site performance taking account of the contingency role of branding in multi-channel retailing. J. Consum. Mark. 2011, 28, 524-531.

61. Speed, R.; Thompson, P. Determinants of sports sponsorship response. J. Acad. Mark. Sci. 2000, 28, 226-238. [CrossRef]

62. Insightxplore. iPhone Users Increased by 5\%; Smart TV Box/ Stick Use Reached 10\%. Available online: https:/ /www.ixresearch. com/news/news_02_21_19 (accessed on 10 March 2021).

63. TWNIC. 2020 Taiwan Internet Report. Available online: https://report.twnic.tw/2020/en/index.html (accessed on 10 January 2021).

64. Riordan, C.M.; Gatewood, R.D.; Bill, J.B. Corporate image: Employee reactions and implications for managing corporate social performance. J. Bus. Ethics 1997, 16, 401-412. [CrossRef]

65. Dunlap, R.E. The new environmental paradigm scale: From marginality to worldwide use. J. Environ. Educ. 2008, 40, 3-18. [CrossRef]

66. Perera, L.C.R.; Chaminda, J.W.D. Corporate social responsibility and product evaluation: The moderating role of brand familiarity. Corp. Soc. Responsib. Environ. Manag. 2013, 20, 245-256. [CrossRef]

67. Türkel, S.; Uzunoğlu, E.; Kaplan, M.D.; Vural, B.A. A strategic approach to CSR communication: Examining the impact of brand familiarity on consumer responses. Corp. Soc. Responsib. Environ. Manag. 2016, 23, 228-242. [CrossRef]

68. Godey, B.; Manthiou, A.; Pederzoli, D.; Rokka, J.; Aiello, G.; Donvito, R.; Singh, R. Social media marketing efforts of luxury brands: Influence on brand equity and consumer behavior. J. Bus. Res. 2016, 69, 5833-5841. [CrossRef]

69. Hayes, A.F. Introduction to Mediation, Moderation, and Conditional Process Analysis: A Regression-Based Approach; Guilford Publications: New York, NY, USA, 2018.

70. Tian, Y.; Hung, C.; Frumkin, P. An experimental test of the impact of corporate social responsibility on consumers' purchasing behavior: The mediation role of trust. Corp. Soc. Responsib. Environ. Manag. 2020, 27, 2972-2982. [CrossRef]

71. Strahilevitz, M. The effects of product type and donation magnitude on willingness to pay more for a charity-linked brand. J. Consum. Psychol. 1999, 8, 215-241. [CrossRef]

72. Levitt, T. Marketing intangible products and product intangibles. Cornell Hotel Restaur. Adm. Q. 1981, 22, 37-44. [CrossRef]

73. Rahman, M.; Rodríguez-Serrano, M.Á.; Lambkin, M. Corporate social responsibility and marketing performance: The moderating role of advertising intensity. J. Advert. Res. 2017, 57, 368-378. [CrossRef]

74. Yoon, S.; Oh, S. Introduction to the special issue on social and environmental issues in advertising. Int. J. Advert. 2016, 35, 1-3. [CrossRef] 